\title{
PENGARUH PERAN PENDAMPING DAN MOTIVASI BELAJAR TERHADAP PERUBAHAN PERILAKU KELUARGA PENERIMA MANFAAT (KPM) PROGRAM KELUARGA HARAPAN (PKH)
}

\author{
R.A. Febrianto ${ }^{1}$, Utsman $^{2}$, A. Rifai $\mathrm{RC}^{3}$ \\ ${ }^{1,2,3}$ Program Studi Pendidikan Luar Sekolah, Pascasarjana, \\ Universitas Negeri Semarang, Indonesia \\ e-mail: rendiagungfebrianto@gmail.com ${ }^{1}$, utsman@mail.unnes.ac.id ${ }^{2}$, \\ rifaipls@mail.unnes.ac.id ${ }^{3}$
}

\begin{abstract}
Abstrak
Pengelolaan keuangan keluarga yang buruk banyak ditemui pada Keluarga Penerima Manfaat (KPM) Program Keluarga Harapan (PKH) Kecamatan Suruh Kabupaten Semarang. Program Keluarga Harapan (PKH) dengan kegiatannya yang bernama Pertemuan Peningkatan Kemampuan Keluarga (P2K2) memiliki tujuan hasil belajar berupa perubahan perilaku, salah satunya mengenai pengelolaan keuangan keluarga. Dalam kegiatan P2K2 terdapat faktor internal dan eksternal yang dapat mempengaruhi hasil belajar Keluarga Penerima Manfaat (KPM). Penelitian ini bertujuan untuk menganalisis pengaruh peran pendamping dan motivasi belajar terhadap perubahan perilaku pengelolaan keuangan Keluarga Penerima Manfaat (KPM) baik secara parsial maupun simultan. Jenis penelitian yang digunnakan adalah penelitian kuantitatif. Pengambilan sampel penggunaan tenik probability samping dengan jumblah samel 125 keluarga penerima manfaat (KPM) data hasil koisioner diolah dengan uji regresi linier berganda Hasil penelitian menunjukkan bahwa terdapat pengaruh antara peran pendamping dan motivasi belajar terhadap perubahan perilaku pengelolaan keuangan Keluarga Penerima Manfaat (KPM) Program Keluarga Harapan (PKH) Kecamatan Suruh Kabupaten Semarang.
\end{abstract}

Kata kunci : Peran Pendamping, Motivasi Belajar, Perubahan Perilaku

\begin{abstract}
Poor family financial management is commonly found in Keluarga Penerima Manfaat (KPM) Program Keluarga Harapan (PKH) Kecamatan Suruh Kabupaten Semarang. PKH with its activity called Pertemuan Peningkatan Kemampuan Keluarga (P2K2) have learning outcomes in the form of behavior change, one of them is about family financial management. In P2K2 there are internal and external factors that can affect Keluarga Penerima Manfaat (KPM) learning outcomes. This study aims to analyze the effect of companion role and learning motivation to financial management behavior change of Keluarga Penerima Manfaat (KPM) partially or simultaneously. The type of research is quantitative research. using probability sampling technique with 125 Keluarga Penerima Manfaat as sample. Data from the questionnaire were processed using multiple linear regression tests. The results showed there is an effect between companion role and learning motivation to financial management behavior change of Keluarga Penerima Manfaat (KPM) Program Keluarga Harapan (PKH) Kecamatan Suruh Kabupaten Semarang.
\end{abstract}

Keywords : Companion Role, Learning Motivation, Behavior Change 


\section{PENDAHULUAN}

Pemerintah Indonesia melalui
Kementerian Sosial menyelenggarakan Program Keluarga Harapan (PKH) sebagai salah satu bentuk kegiatan pemberdayaan masyarakat. Secara garis besar menurut Rachmat (2018) pemberdayaan masyarakat adalah segala upaya fasilitasi yang bersifat non instruktif guna meningkatkan pengetahuan dan kemampuan masyarakat agar mampu mengidentifikasi masalah yang dihadapi, potensi yang dimiliki, merencanakan, dan melakukan pemecahannya dengan memanfaatkan potensi setempat. Peraturan Menteri Sosial Republik Indonesia tentang Program Keluarga Harapan Pasal 1 Ayat 1 yang menyatakan bahwa Program Keluarga Harapan adalah program pemberian bantuan sosial bersyarat kepada keluarga dan/atau seseorang miskin. Peraturan Menteri Sosial Nomor 1 Tahun 2018 tentang Program Keluarga Harapan (PKH) Pasal 6 yang menyebutkan bahawa Keluarga Penerima Manfaat (KPM) berhak mendapatkan bantuan sosial $\mathrm{PKH}$, pendampingan $\mathrm{PKH}$, pelayanan di fasilitas kesehatan, pendidikan, dan/atau kesejahteraan sosial, dan program bantuan komplementer di bidang kesehatan pendidikan, subsidi energi, ekonomi, perumahan, dan pemenuhan kebutuhan dasar lainnya.

Kecamatan Suruh memiliki luas wilayah $64,02 \mathrm{Km}^{2}$ yang wilayahnya masuk dalam Kabupaten Semarang. Badan Pusat Statistik (BPS) Kabupaten Semarang menyebutkan bahwa pada tahun 2018 Kecamatan Suruh memiliki jumlah penduduk sebanyak 60.424 jiwa yang penduduknya tersebar di 17 desa yang terdiri dari $101 \mathrm{RW}$ dan $492 \mathrm{RT}$. Data diperoleh dari Program Keluarga Harapan (PKH) Kabupaten Semarang mencatatkan jumlah Keluarga Penerima Manfaat (KPM) di Kabupaten Semarang berjumlah $28.711 \mathrm{KK}$ dan jumlah KPM di Kecamatan Suruh sendiri adalah yang paling besar dengan 2972 KK. Dari hasil tersebut dapat menggambarkan bahwa kecamatan suruh memiliki masyarakat miskin paling banyak di Kabupaten Semarang.

Survei yang dilakukan Program Keluarga Harapan (PKH) menunjukkan bahwa masalah keuangan yang dialami oleh masyarakat miskin umumnya adalah lebih besarnya pengeluaran dibanding pendapatan, serta tidak teraturnya jumlah dan waktu menerima pendapatan. Masalah selanjutnya adalah ketika mengelola hutang, berhutang banyak dilakukan oleh rumah tangga miskin untuk menutupi pengeluaran yang lebih besar dari pada pendapatan yang dihasilkan dan pada saat dilakukan sering kali pertimbangannya tidak matang sehingga mereka rentan terperangkap utang. Selanjutnya usaha mikro yang banyak digeluti oleh rumah tangga miskin sebagai salah satu upaya untuk meningkatkan pendapatan, sebagian berhasil mengembangkan usahanya menjadi sumber penghasilan keluarga yang dapat diandalkan, namun sebagian besar harus menghentikan atau mengganti-ganti jenis usaha karena tidak memberikan keuntungan yang cukup. Salah satu kendala yang dihadapi adalah minimnya pengetahuan untuk merencanakan dan mengelola usaha tersebut.

Observasi dan wawancara yang dilakukan oleh peneliti kepada beberapa kelompok KPM PKH di beberapa desa di Kecamatan Suruh ditketahui bahwa masih banyak KPM dengan pengelolaan keuangan keluarga yang buruk. Beberapa KPM PKH Kecamatan suruh memberikan keterangan bahwa sering kali pendapatannya tidak dapat mencukupi kebutuhan bulanan sehingga untuk menutupnya dengan terpaksa melakukan hutang. Sedangkan idealnya menurut Trisnaningsih dan Widyasari (2010) perencanaan keuangan perlu dilakukan karena semua orang pada dasarnya memiliki ketidakpastian yaitu ketakutan akan masa depan kehidupan finansial, karena pada hakekatnya hidup adalah ketidakpastian dan tidak ada seorangpun yang mampu untuk mencegah kecelakaan, penderitaan, dan kesukaran serta megejar keberuntungan dan nasib baik. Dengan perencanaan keuangan akan memberikan pilihan untuk menghadapi masa depan.

Kegiatan pendampingan dalam $\mathrm{PKH}$ dinamakan Pertemuan Peningkatan Kemampuan Keluarga (P2K2) atau dapat disebut juga dengan Family Developmen Session (FDS). Peraturan Menteri Sosial Nomor 1 Tahun 2018 tentang Program Keluarga Harapan Pasal 1 Ayat 16 menjelaskan bahwa Pertemuan Peningkatan Kemampuan Keluarga adalah proses belajar secara terstruktur untuk mempercepat terjadinya perubahan perilaku pada Keluarga Penerima Manfaat PKH. Kegiatan Pertemuan Peningkatan Kemampuan Keluarga (P2K2) merupakan pertemuan rutin yang dilaksanakan minimal satu bulan sekali antara pendamping $\mathrm{PKH}$ dan KPM. Pada kegiatan ini pendamping dapat memantau perkembangan dari KPM, melakukan pengecekan penyaluran bantuan, dan memberikan materi pembelajaran yang ada pada modul PKH. Sesuai dengan pernyataan Amanah (2007) yang menyebutkan bahwa pendampingan 
merupakan upaya yang dilakukan untuk mendorong terjadinya perubahan perilaku pada individu, kelompok, komunitas, atau masyarakat agar mereka tahu, mau, dan mampu menyelesaikan permasalahan yang dihadapi supaya memiliki kehidupan yang berkualitas dan bermartabat.

Penyampaian materi dalam kegiatan P2K2 pada pelaksanaannya berpegang pada 5 modul yang disampaikan, salah satu dari modul tersebut adalah modul pengelolaan keuangan keluarga. Dalam modul ini terdapat 2 pembahasan yaitu pengelolaan keuangan keluarga dan perencanaan usaha. Tujuan disampaikannya modul ini agar KPM dapat mengubah perilaku mengelola keuangan keluarga baik itu uang pendapatan dari bekerja dan uang dari bantuan $\mathrm{PKH}$ seta dapat memulai sebuah usaha sebagai cara lepas dari kemiskinan. Pemberian modul P2K2 tentang pengelolaan keuangan keluarga dan perencanaan usaha pada Keluarga Penerima Manfaat (KPM) PKH di Kecamatan Suruh cukup menarik untuk dibahas mengingat kemiskinan yang cukup erat kaitannya dengan pengelolaan keuangan dan modul pengelolaan keuangan keluarga merupakan salah satu solusi melalui pendidikan dari PKH agar KPM dapat terlepas dari belenggu kemiskinan.

Kegiatan P2K2 sejatinya adalah kegiatan belajar non formal proses transfer ilmu yang di dalamnya pendamping $\mathrm{PKH}$ berperan sebagai guru dan KPM adalah murid. Terdapat faktor internternal dan eksternal yang mempengaruhi efektifitas dalam kegiatan belajar. Salah satu faktor internal yang mempengaruhi belajar adalah motivasi belajar. Menurut Suhana (2014) motivasi belajar merupakan kekuatan daya pendorong, atau alat pembangun kesediaan dan keinginan yang kuat dalam diri peserta didik untuk belajar secara aktif, kreatif, efektif, inovatif, dan menyenangkan dalam rangka perubahan perilaku baik dalam aspek kognitif, afektif, dan psikomotor. Berdasarkan teori tersebut peneliti bertujuan mengukur korelasi dari motivasi belajar KPM PKH Kecamatan Suruh terhadap hasil belajar yang berbentuk perubahan perilaku khususnya pada pengelolaan keuangan Keluarga Penerima Manfaat (KPM). Selanjutnya Slameto (2010) menyatakan bahwa guru dengan cara mengajarnya merupakan faktor eksternal di luar individu yang mempengaruhi hasil belajar siswa. Pada penelitian ini yang berperan sebagai guru dalam kegiatan Pertemuan Peningkatan Kemampuan Keluarga (P2K2) adalah pendamping $\mathrm{PKH}$. Sesuai dengan tugasnya pendamping $\mathrm{PKH}$ tidak hanya memastikan bantuan sampai ke tangan KPM tetapi juga memberikan pembelajaran melalui kegiatan P2K2. Terkait peran pendamping $\mathrm{PKH}$ sebagai guru dalam kegiatan P2K2, Sanjaya (2007) berpendapat bahwa guru memiliki beberapa peran dalam kegiatan pembelajaran yaitu sebagai sumber belajar siswa, guru sebagai fasilitator, guru sebagai pengelola kegiatan pembelajaran, guru sebagai demonstrator, guru sebagai motivator, dan yang terakhir adalah guru sebagai evaluator. Tentunya peran-peran tersebut harus dijalankan oleh pendamping $\mathrm{PKH}$ pada saat pelaksanaan kegiatan Pertemuan Peningkatan Kemampuan Keluarga (P2K2). Apakah pendamping $\mathrm{PKH}$ saat melaksanakan kegiatan P2K2 sudah menjalankan peran-perannya sebagai guru, mengingat peran guru dalam kegiatan belajar dapat mempengaruhi hasil belajar siswanya.

Dari masalah yang sudah di uraikan dapat diketahui bahwa masyarakat miskin di Kecamatan Suruh dapat dikatakan tinggi ditandai dengan jumlah Keluarga Penerima Manfaat (KPM) PKH Kecamatan suruh adalah yang paling tinggi di Kabupaten Semarang. PKH Kecamatan Suruh dengan kegiatan P2K2 khususnya pada materi pengelolaan keuangan keluarga dan perencanaan usaha diharapkan dapat mengedukasi KPM agar dapat mengelola keuangan keluarganya sebagai solusi usaha terlepas dari kemiskinan. Kegiatan Pertemuan Peningkatan Kemampuan Keluarga (P2K2) sejatinya adalah kegiatan belajar mengajar non formal yang di dalamnya terdapat pendamping $\mathrm{PKH}$ sebagai guru dan KPM sebagai muridnya. Pada Kegiatan P2K2 Pentingnya peran pendamping $\mathrm{PKH}$ sebagai guru merupakan salah satu faktor eksternal dan motivasi belajar KPM yang merupakan salah satu faktor internal yang mempengaruhi hasil belajar KPM berupa perubahan perilaku pengelolaan keuangan, selanjutnya dapat diketahui sejauh mana efektifitas kegiatan P2K2 PKH Kecamatan Suruh khususnya pada pengelolaan keuangan Keluarga Penerima Manfaat (KPM). Dari uraian tersebut peneliti tertarik untuk meneliti tentang pengaruh peran pendamping dan motivasi belajar terhadap perubahan perilaku pengelolaan keuangan Keluarga Penerima Manfaat PKH Kecamatan Suruh baik secara parsial maupun simultan.

Hipotesis dalam penelitian ini yaitu $\mathrm{H} 1$ : Peran pendamping berpengaruh terhadap perubahan perilaku pengelolaan keuangan Keluarga Penerima Manfaat (KPM) Program Keluarga Harapan (PKH). H2: Motivasi belajar berpengaruh terhadap perubahan perilaku pengelolaan keuangan Keluarga Penerima Manfaat (KPM) Program Keluarga Harapan 
(PKH). H3: Peran pendamping dan motivasi belajar secara bersama-sama berpengaruh terhadap perubahan perilaku pengelolaan keuangan Keluarga Penerima Manfaat (KPM) Program Keluarga Harapan (PKH).

\section{METODE}

Jenis Penelitian ini tergolong kedalam jenis penelitian Kuantitatif. Rancangan dalam penelitian ini adalah rancangan penelitian korelasional yaitu meneliti hubungan dari variabel. Dengan mengetahui tingkat hubungan yang ada, peneliti akan dapat mengembangkannya sesuai dengan tujuan penelitian. Data kuantitatif adalah data yang berbentuk angka, atau data kualitatif yang diangkakan (Sugiyono, 2008). Penelitian korelasional dimaksudkan untuk mengetahui adanya pengaruh antara variabel dependen (variabel terikat) dan variabel independen (variabel bebas). Penelitian difokuskan terhadap Keluarga Penerima Manfaat (KPM) Program Keluarga Harapan (PKH) Kecamatan Suruh Kabupaten Semarang. Penelitian ini dilakukan untuk membuktikan pengaruh Pengaruh Peran Pendamping dan Motivasi Belajar sebagai variabel bebas (Independen) terhadap Perubahan Perilaku Pengelolaan Keuangan sebagai variabel terikat (Dependen).

Penelitian bertempat di Kecamatan Suruh Kabupaten Semarang. Alasan pengambilan tempat penelitian dikarenakan Kecamatan Suruh memiliki Keluarga Penerima Manfaat (KPM) Program Keluarga Harapan (PKH) sejumlah 2972, jumlah ini merupakan yang terbanyak di antara kecamatan lain di Kabupaten Semarang. Penelitian dilaksanakan pada bulan Maret 2020 - April 2020. Populasi dalam penelitian ini adalah Keluarga Penerima Manfaat (KPM) Program Keluarga Harapan (PKH) Kecamatan Suruh Kabupaten Semarang sejumlah 2972. Pengambilan sampel digunakan teknik probability sampling dengan menggunakan area sampling (cluster sampling). Desa yang dijadikan sampel penelitian berjumlah 6 desa yaitu Medayu, Gunung Tumpeng, Bonomerto, Sukorejo, Reksosari, dan Suruh. Pada tahap selanjutnya peneliti melakukan pembatasan pengambilan sampel penelitian dengan hanya mengambil Keluarga Penerima Manfaat (KPM) dengan tahun kepesertaan 2011 sejumlah 181 KPM. Besaran ukuran sampel dalam penelitian ini ditetapkan menggunakan rumus Slovin dengan batas toleransi kesalahan 5\% yaitu sebagai berikut:

$$
\begin{aligned}
& \mathrm{n}=\frac{N}{1+N e^{2}} \\
& \mathrm{n}=\frac{181}{1+181(0,05)^{2}} \\
& \mathrm{n}=124,61 \text { dibulatkan menjadi } 125
\end{aligned}
$$

Keterangan:

$\mathrm{n}=$ Ukuran sampel

$\mathrm{N}=$ Ukuran populasi

$\mathrm{e}=$ Batas tolerasi kesalahan

Dari hasil perhitungan rumus Slovin tersebut minimal sampel yang dapat digunakan dalam penelitian ini adalah 125 KPM dengan rincian sebagai berikut :

Tabel 1. Ukuran Pengambilan Sampel

\begin{tabular}{llll}
\hline Desa & KPM 2011 & KPM & Sampel \\
\hline Medayu & 13 & 8,97 & 9 \\
Bonemerlo & 18 & 12,43 & 12 \\
Sukerejo & 28 & 19,33 & 19 \\
Gurung Tumpeng & 30 & 20,71 & 21 \\
Reksosari & 40 & 27,62 & 28 \\
Suruh & 52 & 35,91 & 36 \\
Jumblah & & & 125 \\
\hline
\end{tabular}

Pengumpulan data pada penelitian ini menggunakan kuesioner. Kuesioner disusun berdasarkan skala Likert dengan memberikan penilaian atas jawaban responden dengan skor Sangat Setuju (5), Setuju (4), Ragu-Ragu (3), Tidak Setuju (2), Sangat Tidak Setuju (1). Uji instrumen dilakukan sebelum penelitian dengan tujuan untuk memperoleh informasi mengenai kualitas instrumen sudah atau belum memenuhi persyaratan yang digunakan. Instrumen yang baik harus valid dan reliabel. Data yang diperoleh diuji menggunakan IBM SPSS 23 Uji Regresi Linier Berganda diawali dengan uji Asumsi Klasik. 


\section{HASIL DAN PEMBAHASAN}

Tabel 2. Uji Validitas

\begin{tabular}{ccccc}
\hline Item & $\mathrm{r}$ tabel $(0,05)$ & Peran Pendamping & Motivasi Belajar & Perubahan Perilaku \\
\hline P1 & 0,3610 & 0,459 & 0,376 & 0,449 \\
\hline P2 & 0,3610 & 0,375 & 0,687 & 0,625 \\
\hline P3 & 0,3610 & 0,398 & 0,364 & 0,479 \\
\hline P4 & 0,3610 & 0,423 & 0,377 & 0,394 \\
\hline P5 & 0,3610 & 0,435 & 0,530 & 0,512 \\
\hline P6 & 0,3610 & 0,391 & 0,421 & 0,678 \\
\hline P7 & 0,3610 & 0,411 & 0,458 & 0,399 \\
\hline P8 & 0,3610 & 0,520 & 0,413 & 0,680 \\
\hline P9 & 0,3610 & 0,528 & 0,426 & 0,773 \\
\hline P10 & 0,3610 & 0,392 & 0,534 & 0,393 \\
\hline P11 & 0,3610 & 0,373 & 0,440 & 0,495 \\
\hline P12 & 0,3610 & 0,610 & 0,524 & 0,609 \\
\hline P13 & 0,3610 & 0,391 & 0,366 & 0,410 \\
\hline P14 & 0,3610 & 0,383 & 0,415 & 0,423 \\
\hline P15 & 0,3610 & 0,659 & 0,423 & 0,436 \\
\hline
\end{tabular}

Berdasarkan hasil uji validitas variabel Peran Pendamping, Motivasi Belajar, dan Perubahan Perilaku Pengelolaan Keuangan didapatkan hasil nilai $r$ hitung masing-masing

Tabel 3. Uji Reliabilitas item pertanyaan menunjukkan nilai $r$ hitung $>r$ tabel yang berarti setiap item pertanyaan dinyatakan valid.

\begin{tabular}{lc}
\hline \multicolumn{1}{c}{ Variabel } & Cronbach's Alpha \\
\hline Peran Pendamping & 0,693 \\
\hline Motivasi Belajar & 0,714 \\
\hline Perubahan Perilaku & 0,786
\end{tabular}

Berdasarkan hasil uji reliabilitas variabel Peran Pendamping didapatkan hasil nilai Cronbach's Alpha sebesar 0,693 > 0,6, variabel Motivasi Belajar sebesar 0,714 >0,6,

Tabel 4. Responden Penelitian dan variabel Perubahan Perilaku Pengelolaan Keuangan sebesar $0,786>0,6$ sehingga kuesioner dinyatakan reliabel atau konsisten.

\begin{tabular}{ccc}
\hline Desa & Frekuensi & Persentase \\
\hline Medayu & 9 & $7,2 \%$ \\
\hline Bonomerto & 12 & $9,6 \%$ \\
\hline Sukorejo & 19 & $15,2 \%$ \\
\hline Gunung Tumpeng & 21 & $16,8 \%$ \\
\hline Reksosari & 28 & $22,4 \%$ \\
\hline Suruh & 36 & $28,8 \%$ \\
\hline Jumlah & $\mathbf{1 2 5}$ & $\mathbf{1 0 0} \%$ \\
\hline
\end{tabular}

Responden dalam penelitian ini adalah Keluarga Penerima Manfaat (KPM) PKH dengan tahun kepesertaan 2011 dari enam desa yang yang sudah dipilih untuk mewakili dalam penelitian yaitu Medayu, Bonomerto,
Sukorejo, Gunung Tumpeng, Reksosari, dan Suruh. Responden yang digunakan dalam penelitian yaitu sejumlah $125 \mathrm{KPM}$. 
Tabel 5. Responden Berdasarkan Jenis Kelamin

\begin{tabular}{ccc}
\hline Jenis Kelamin & Frekuensi & Persentase \\
\hline Perrempuan & 120 & $96 \%$ \\
\hline Laki-Laki & 5 & $4 \%$ \\
\hline Jumlah & 125 & $100 \%$
\end{tabular}

Setelah kuesioner disebarkan kepada 125 responden yang tersebar di enam desa di Kecamatan Suruh dapat diklasifikasikan berdasarkan jenis kelamin yang diketahui bahwa responden didominasi oleh perempuan yang berjumlah 120 orang atau $96 \%$ dan sisanya responden laki-laki yang berjumlah 5 orang atau $4 \%$.

Tabel 6. Persentase Peran Pendamping

\begin{tabular}{lllll}
\hline Skor & Klasifikasi & Peran pedagang & $\begin{array}{l}\text { Peran } \\
\text { Pendamping }\end{array}$ & $\begin{array}{l}\text { Perubahan } \\
\text { Prilaku }\end{array}$ \\
\hline $61-75$ & Sangat Setuju & $22,4 \%$ & $19,2 \%$ & $2,4 \%$ \\
$46-60$ & Setuju & $72,8 \%$ & $68,8 \%$ & $75 \%$ \\
$31-45$ & Ragu -Ragu & $4,8 \%$ & $12,0 \%$ & $22,4 \%$ \\
$16-30$ & Tidak Setuju & $0,0 \%$ & $0,0 \%$ & $0,0 \%$ \\
$1-15$ & Sangat tidak & $0,0 \%$ & $0,0 \%$ & $0,0 \%$ \\
& setuju & & & \\
\hline
\end{tabular}

Tabel 6 menunjukkan jawaban responden pada variabel peran pendamping sebesar $72,8 \%$ responden menyatakan setuju, selanjutnya $22,4 \%$ rensponden menyatakan sangat setuju, dan $4,8 \%$ responden menyatakan ragu-ragu. Jawaban pada variabel motivasi belajar menunjukkan bahwa $68,8 \%$ responden menyatakan setuju, selanjutnya 19,2\% rensponden menyatakan sangat setuju, dan $12 \%$ responden menyatakan ragu-ragu. Jawaban pada variabel perubahan perilaku pengelolaan keuangan menunjukkan bahwa 75,2\% responden menyatakan setuju, selanjutnya $22,4 \%$ rensponden menyatakan ragu-ragu, dan $3 \%$ responden menyatakan sangat setuju.

Tabel 7. Uji Normalitas

\begin{tabular}{cc}
\hline Variabel & Signifikansi \\
\hline Peran Pendamping & 0,190 \\
\hline Motivasi Belajar & 0,169 \\
\hline Perubahan Perilaku Pengelolaan Keuangan & 0,175
\end{tabular}

Berdasarkan hasil Uji Normalitas data dengan Kolmogorov-Smirnov pada variabel Peran Pendamping menghasilkan nilai signifikansi 0,190>0,05, variabel Motivasi Belajar menunjukkan nilai signifikansi 0,169 >
0,05, dan pada variabel Perubahan Perilaku Pengelolaan Keuangan menunjukkan nilai signifikansi 0,175 > 0,05 dari ketiga variabel tersebut dapat disimpulkan bahwa data berdistribusi normal.

Tabel 8. Uji Linearitas

\begin{tabular}{ll}
\hline Variabel & Sig \\
\hline Peran Pendamping*Perubahan Perilaku Pengelolaan Keuangan & 0,590 \\
\hline Motivasi Belajar* Perubahan Perilaku Pengelolaan Keuangan & 0,395 \\
\hline
\end{tabular}

Berdasarkan hasil uji linearitas variabel Peran Pendamping dengan Perubahan Perilaku Pengelolaan Keuangan didapatkan hasil nilai signifikansi $0,590>0,05$ sehingga dapat disimpulkan terdapat hubungan yang linear secara signifikan antara variabel Peran Pendamping (X1) dengan variabel Perubahan
Perilaku Pengelolaan Keuangan (Y). Berdasarkan hasil uji linearitas variabel Motivasi Belajar dengan Perubahan Perilaku Pengelolaan Keuangan didapatkan hasil nilai signifikansi $0,395>0,05$ sehingga dapat disimpulkan terdapat hubungan yang linear secara signifikan antara variabel Motivasi 
Belajar (X2) dengan variabel Perubahan

Perilaku Pengelolaan Keuangan (Y).

Tabel 9. Uji Multikolinearitas

\begin{tabular}{lll}
\hline Variabel & Tolerance & VIF \\
\hline Peran Pendamping & 0,954 & 1,048 \\
\hline Motivasi Belajar & 0,954 & 1,048 \\
\hline
\end{tabular}

Variabel terikat: Perubahan Perilaku Pengelolaan Keuangan

Berdasarkan hasil uji multikolinearitas diatas dapat diketahui nilai tolerance dan nilai VIF untuk dasar pengambilan keputusan. Berasarkan nilai tolerance variabel Peran Pendamping (X1) dan variabel Motivasi Belajar (X2) adalah 0,954 > 0,10. Sedangkan nilai VIF

Tabel 10. Uji Heterokedastisitas untuk variabel Peran Pendamping (X1) dan variabel Motivasi Belajar (X2) adalah 1,048 < 10. Maka dapat disimpulkan bahwa tidak terjadi gejala Multikolinearitas dalam model regresi.

\begin{tabular}{lcc}
\hline \multicolumn{1}{c}{ Variabel } & Koefisien Korelasi & Sig \\
\hline Peran Pendamping*Perubahan Perilaku Pengelolaan Keuangan & 0,231 & 0,009 \\
Motivasi Belajar* Perubahan Perilaku Pengelolaan Keuangan & 0,269 & 0,002 \\
\hline
\end{tabular}

$\begin{array}{rrr}\begin{array}{c}\text { Berdasarkan } \\ \text { Heteroskedastisitas }\end{array} & \text { hasil } & \text { Uji } \\ \text { vabiabl } & \text { Peran }\end{array}$

Pendamping (X1) diperoleh angka koefisien korelasi sebesar 0,231 yang berarti tingkat kekuatan korelasi (hubungan) antara variabel Peran Pendamping dengan Perubahan Perilaku Pengelolaan Keuangan adalah sebesar 0,231 atau hubungan sangat lemah. Angka koefisien korelasi bernilai positif yaitu 0,231 yang berarti hubungan kedua variabel tersebut bersifat searah, yang dapat diartikan jika Peran Pendamping semakin ditingkatkan maka Perubahan Perilaku Pengelolaan Keuangan juga akan semakin meningkat. Hasil nilai signifikansi yaitu 0,009 $<0,05$ yang berarti terdapat hubungan yang signifikan (berarti) antara variabel Peran Pendamping dan Perubahan Perilaku Pengelolaan Keuangan.

Berdasarkan hasil Uji
Heteroskedastisitas variabel Motivasi Belajar (X2) diperoleh angka koefisien korelasi sebesar 0,269 yang berarti tingkat kekuatan korelasi (hubungan) antara variabel Peran Pendamping dengan Perubahan Perilaku Pengelolaan Keuangan adalah sebesar 0,269 atau hubungan cukup. Angka koefisien korelasi bernilai positif yaitu 0,269 yang berarti hubungan kedua variabel tersebut bersifat searah, yang dapat diartikan jika Motivasi Belajar semakin ditingkatkan maka Perubahan Perilaku Pengelolaan Keuangan juga akan semakin meningkat. Hasil nilai signifikansi yaitu $0,002<0,05$ yang berarti terdapat hubungan yang signifikan (berarti) antara variabel Motivasi Belajar dan Perubahan Perilaku Pengelolaan Keuangan. pada versadarkan uji deskriptif dengan SPSS menunjukkan jumlah responden $(\mathrm{N})$ sebanyak 125. Penjumlahan total skor variabel Peran Pendamping adalah 6877 dengan nilai skor terendah adalah 44 , nilai skor tertinggi adalah 65, mean (rata-rata) adalah 55,02 dan Standar deviasi variabel adalah 5,834. Nilai skewness dan kurtosis data diatas mendekati angka nol dengan nilai skewness adalah 0,021 dan nilai kurtosis $-1,035$ sehingga menunjukkan bahwa data terdistribusi normal.

Hasil pada variabel Motivasi Belajar menunjukkan jumlah responden $(\mathrm{N})$ sebanyak 125. Penjumlahan total skor variabel Motivasi Belajar adalah 6761 dengan nilai skor terendah adalah 42 , nilai skor tertinggi adalah 64, mean (rata-rata) adalah 54,09 dan Standar deviasi variabel adalah 6,231. Nilai skewness dan kurtosis data diatas mendekati angka nol dengan nilai skewness adalah 0,172 dan nilai kurtosis $-0,967$ sehingga menunjukkan bahwa data terdistribusi normal.

Hasil pada variabel Perubahan Perilaku Pengelolaan Keuangan menunjukkan jumlah responden $(\mathrm{N})$ sebanyak 125 . Penjumlahan total skor variabel Perubahan Perilaku Pengelolaan Keuangan adalah 6972 dengan nilai skor terendah adalah 45 , nilai skor tertinggi adalah 68, mean (rata-rata) adalah 55,78 dan Standar deviasi variabel adalah 5,921 . Nilai skewness dan kurtosis data diatas mendekati angka nol dengan nilai skewness adalah 0,225 dan nilai kurtosis $-0,645$ sehingga menunjukkan bahwa data terdistribusi normal. 
Tabel 11. Uji Regresi Linier Berganda

\begin{tabular}{lccc}
\hline \multicolumn{1}{c}{ Variabel } & Koefisien Regresi & t. Hitung & Sig. \\
\hline Konstanta & 34,744 & & \\
\hline Peran Pendamping & & 2,105 & 0,037 \\
\hline Motivasi Belajar & & 2,351 & 0,020 \\
\hline
\end{tabular}

F Hitung $\quad=6,334$

$\mathrm{R}$ Square $\quad=0,094$

Berdasarkan t hitung dan t tabel variabel Peran Pendamping dapat diketahui bahwa nilai t hitung $>t$ tabel yaitu 2,105 $>1,979$ yang berarti terdapat pengaruh Peran Pendamping terhadap perubahan perilaku pengelolaan keuangan Keluarga Penerima Manfaat (KPM) Program Keluarga Harapan (PKH). Berdasarkan nilai Signifikansi variabel Peran Pendamping sebesar 0,037 $<0,05$ yang berarti terdapat pengaruh Peran Pendamping terhadap perubahan perilaku pengelolaan keuangan Keluarga Penerima Manfaat (KPM) Program Keluarga Harapan (PKH).

Berdasarkan $\mathrm{t}$ hitung dan $\mathrm{t}$ tabel variable Motivasi Belajar dapat diketahui bahwa nilai $t$ hitung > $t$ tabel yaitu 2,351 > 1,979 yang berarti terdapat pengaruh Motivasi Belajar terhadap perubahan perilaku pengelolaan keuangan Keluarga Penerima Manfaat (KPM) Program Keluarga Harapan (PKH). Nilai signifikansi variabel Motivasi Belajar menunjukkan 0,02 $<0,05$ yang berarti terdapat pengaruh Motivasi Belajar berpengaruh terhadap perubahan perilaku pengelolaan keuangan Keluarga Penerima Manfaat (KPM) Program Keluarga Harapan (PKH).

Berdasarkan hasil perhitungan nilai $F$ didapatkan hasil $F$ hitung $>\mathrm{F}$ tabel yaitu 6,334 $>3,070$ yang berarti Peran Pendamping (X1) dan Motivasi Belajar (X2) secara bersamasama berpengaruh terhadap Perubahan Periaku Pengelolaan Keuangan (Y). Berdasarkan nilai $R$ square tabel diatas dapat diketahui bahwa kontribusi pengaruh variabel Peran Pendamping (X1) dan Motivasi Belajar (X2) secara simultan terhadap Perubahan Perilaku Pengelolaan Keuangan yaitu sebesar $9,4 \%$ sedangkan sisanya sebesar 90,6\% dipengaruhi oleh faktor lain diluar variabel yang di teliti.

Hasil pada penelitian ini menunjukkan bahwa terdapat pengaruh antara peran pendamping terhadap perubahan perilaku pengelolaan keuangan Keluarga Penerima Manfaat (KPM) Program Keluarga Harapan (PKH) Kecamatan Suruh, maka dapat disimpulkan bahwa $\mathrm{H} 1$ penelitian diterima. Besaran nilai sumbangan relatif peran pendamping terhadap perubahan perilaku pengelolaan keuangan sebesar $45,74 \%$.
Selanjutnya, nilai sumbangan efektif peran pendamping terhadap perubahan perilaku pengelolaan keuangan adalah $4,3 \%$.

Peran pendamping $\mathrm{PKH}$ Kecamatan Suruh menunjukkan angka yang tinggi yaitu sebesar $72 \%$. Pendamping berperan dalam perubahan perilaku pengelolaan keuangan karena pendamping memberikan informasi dan membimbing peserta sehingga pendamping dianggap orang yang paling memiliki keahlian di bidang tersebut sehingga KPM terdorong untuk mempercayai pendamping dalam perilaku pengelolaan keuangannya. Temuan ini mendukung teori peran guru sebagai demonstrator yang beranggapan bahwa guru harus menguasai materi sehingga memudahkan siswa dalam belajar dan sikap yang dimilikinya dapat menjadi contoh.

Penelitian ini relevan dengan penelitian yang dilakukan sebelumnya oleh Suryana, dkk (2016) yang menyebutkan bahwa peran pendamping Program Keluarga Harapan (PKH) berpengaruh terhadap perubahan perilaku Rumah Tangga Sangat Miskin (RTSM). Peran yang dilakukan pendamping PKH dalam mengelola kegiatan Program Keluarga Harapan merupakan kesan yang dibentuk RTSM untuk menilai keahlian pendamping $\mathrm{PKH}$. Rumah Tangga Sangat Miskin akan menilai pendamping $\mathrm{PKH}$ memiliki keahlian yang tinggi apabila mereka memandang bahwa pendamping $\mathrm{PKH}$ itu cerdas, mampu, ahli, tahu banyak, berpengalaman, dan terlatih. Dengan demikian dapat dikemukakan bahwa semakin tinggi peran yang dilakukan pendamping Program Keluarga Harapan (PKH) maka semakin tinggi pula perubahan perilaku Rumah tangga Sangat Miskin (RTSM).

Pendamping PKH Kecamatan Suruh melakukan inovasi baru dan menggunakan media belajar dalam menyampaikan pembelajarannya sehingga KPM tidak merasa bosan saat materi disampaikan maupun saat implementasi materi. Adanya inovasi tersebut membuat KPM merasa tertarik untuk hadir dalam pertemuan sehingga pendamping dapat dengan mudah menggiring KPM untuk melakukan perubahan pengelolaan keuangan. 
Temuan ini mendukung teori peran guru sebagai fasilitator yang beranggapan bahwa guru harus mampu mengusahakan sumber belajar sehingga dapat memberikan kemudahan pada siswa. Hal ini sesuai dengan pendapat Putri dan Ma'ruf (2016) dalam penelitiannya yang menyatakan bahwa selain modul pembelajaran dan juga sarana pelengkapnya, pendamping juga berinovasi untuk dapat meningkatkan ketertarikan peserta terhadap program pelatihan.

Pendamping juga PKH Kecamatan Suruh melakukan evaluasi pada setiap KPM mengenai materi yang disampaikan sehingga akan timbul semangat dari KPM untuk melakukan perubahan ke arah yang lebih baik. Evaluasi yang dilakukan oleh pendamping juga bertujuan untuk tercapainya hasil perubahan pengelolaan keuangan KPM. Temuan ini mendukung teori peran guru sebagai evaluator yang beranggapan bahwa guru harus dapat mengumpulkan informasi tentang berbagai kelemahan dalam proses pembelajaran untuk perbaikan selanjutnya. Sejalan dengan hasil penelitian ini, Sartika dan Dahlan (2018) dalam penelitiannya menyatakan bahwa peran guru berpengaruh terhadap hasil belajar siswa. Guru mentransfer pengetahuan dan keterampilan yang dimilikinya melaui pelaksanakan kewajiban pembelajaran secara professional dan bertanggung jawab dengan tujuan mencapai hasil belajar yang diharapkan.

Hasil pada penelitian ini menunjukkan bahwa terdapat pengaruh antara motivasi belajar terhadap perubahan perilaku pengelolaan keuangan Keluarga Penerima Manfaat (KPM) Program Keluarga Harapan $(\mathrm{PKH})$ Kecamatan Suruh, maka dapat disimpulkan bahwa $\mathrm{H} 2$ penelitian diterima. Besaran nilai sumbangan relatif sebesar $54,25 \%$. Selanjutnya, nilai sumbangan efektif motivasi belajar terhadap perubahan perilaku pengelolaan keuangan adalah $5,1 \%$.

Motivasi belajar KPM PKH Kecamatan Suruh menunjukkan angka yang tinggi yaitu sebesar 68,8\%. Motivasi belajar KPM PKH Kecamatan suruh timbul karena adanya kemauan dari dalam diri sendiri dan motivasi dari pendamping $\mathrm{PKH}$ untuk merubah pengelolaan keuangannya dengan lebih baik sehingga hasil belajar pada KPM akan tercapai yaitu tercapainya perubahan perilaku pengelolaan keuangan. Temuan pada penelitian ini relevan dengan penelitian sebelumnya yang telah dilakukan oleh Budiwibowo dan nurhalim (2016) yang menyebutkan bahwa Motivasi belajar berpengaruh pada hasil belajar. Motivasi belajar warga belajar akan mempengaruhi prestasi belajarnya, dapat disimpulkan jika seorang warga belajar memiliki motivasi belajar dengan baik maka warga belajar tersebut juga memiliki hasil belajar yang baik pula. Hasil belajar warga belajar dikualifikasikan menjadi tiga ranah yaitu kognitif, afektif, dan psikomotorik. Terutama ditekankan pada aspek psikomotorik, kemampuan psikomotorik yang baik dapat dilihat dari kemampuan warga belajar dalam menerapkan keterampilan yang telah diperolehnya selama proses pembelajaran dan melakukan penerapannya dalam kehidupan sehari-hari.

Keinginan dan kebutuhan untuk melakukan perubahan merupakan suatu dorongan untuk KPM mau dan dengan sukarela menghadiri pertemuan dengan harapan mereka akan mendapatkan perubahan pada kehidupan yang lebih baik lagi untuk kedepannya, dengan motivasi yang tinggi dari KPM PKH Kecamatan Suruh akan memudahkan terjadinya perubahan pada perilaku pengelolaan keuangan. Sejalan dengan hasil penelitian ini Rahayu (2016) menyebutkan bahwa semakin tinggi motivasi belajar warga belajar, maka akan semakin baik pula hasil belajarnya yang berarti terdapat korelasi yang signifikan antara motivasi belajar warga belajar dengan hasil belajarnya. Oleh karena itu dapat dikatakan bahwa semakin tinggi motivasi belajar yang dimiliki oleh warga belajar akan memberikan korelasi yang signifikan dengan peningkatan hasil belajar.

Faktor keuangan yang buruk memicu KPM PKH Kecamatan Suruh untuk mau belajar untuk lebih baik lagi dalam mengelola keuangannya sehingga KPM memiliki harapan pengelolaan keuangan dan taraf hidupnya akan semakin baik. Hal ini sesuai dengan pendapat Mandell dan Klein (2007) menemukan bahwa motivasi merupakan faktor yang dominan mempengaruhi seseorang membuat rencana keuangan. Ketika seseorang memiliki motivasi yang tinggi maka akan mempengaruhi usahanya untuk mewujudkan sesuatu. Seseorang akan berusaha untuk mempelajari kondisi keuangannya pada saat ini untuk diperbaiki di masa yang akan datang melalui pembuatan rencana keuangan yang tepat.

Hasil pada penelitian ini menunjukkan bahwa terdapat pengaruh antara peran pendamping dan motivasi belajar secara bersama-sama terhadap perubahan perilaku pengelolaan keuangan sebesar $9,4 \%$.

Peran pendamping dan motivasi belajar secara bersama-sama mempengaruhi perubahan perilaku pengelolaan keuangan 
KPM PKH Kecamatan Suruh hal tersebut terjadi karena salah satu peran pendamping adalah sebagai motivator untuk meningkatkan motivasi belajar KPM sehingga diharapkan akan mempercepat tercapainya perubahan perilaku pengelolaan keuangan. Sesuai teori peran guru pendamping $\mathrm{PKH}$ Kecamatan suruh sudah memenuhi berbagai perannya dalam pembelajaran yaitu sebagai organisator, motivator, demonstrator, fasilitator, dan evaluator dengan tujuan mempercepat perubahan perilku pada pengelolaan keuangan KPM PKH Kecamatan Suruh. Temuan dalam penelitian ini relevan dengan penelitian yang dilakukan sebelumnya oleh Astriyani dan Triyono (2018) berdasarkan hasil analisis pada variabel penelitian, diperoleh korelasi yang kuat antara motivasi belajar dan peran guru terhadap prestasi belajar secara simultan. Pada penelitian ada empat indikator yang dipilih untuk mengidentifikasi motivasi belajar siswa, yaitu perhatian, keterkaitan, kepuasan, dan rasa percaya diri. Analisis peran guru terhadap prestasi belajar juga menunjukkan adanya hubungan atau korelasi. Pada penelitian ini terdapat tiga indikator yang digunakan untuk mengidentifikasi adanya hubungan peran guru dengan prestasi belajar, yaitu memahami karakter siswa, memberikan motivasi kepada siswa, dan mengorganisir kegiatan pembelajaran. Dari hasil analisis juga diperoleh hubungan yang kuat antara peran guru dengan prestasi belajar siswa. Hal ini mengindikasikan variabel motivasi belajar dan tindakan guru diperlukan oleh siswa untuk meningkatkan prestasi belajar.

Pendamping $\mathrm{PKH}$ Kecamatan Suruh merupakan sosok yang dianggap KPM memiliki pengetahuan yang luas mengenai pengelolaan keuangan sehingga KPM memiliki keinginan untuk memiliki pengetahuan yang sama dengan pendamping dalam masalah pengelolaan keuangan, oleh karena itu timbul motivasi dari dalam diri peserta untuk menghadiri pertemuan dan mengimplementasikan hasil pertemuan ke kehidupan sehari-hari untuk tujuan perubahan yang lebih baik lagi dalam pengelolaan keuangan peserta KPM. Sejalan dengan hasil penelitian ini Setyawati dan Subowo (2018) menyebutkan bahwa peran guru sebagai sangat tinggi dalam mendukung hasil belajar siswa karena guru ialah sosok yang menjadi teladan. Seluruh perilaku guru akan menjadi contoh atau teladan bagi siswa. Peran guru yang tinggi dalam mendidik serta membimbing dan menjadi teladan dalam sikap disiplin, maka akan mewujudkan sikap disiplin belajar dan mencapai hasil belajar yang tinggi pula pada diri siswa. Motivasi belajar dapat dipengaruhi oleh faktor dari dalam diri maupun luar. Motivasi yang bersumber dari faktor dalam diri akan menghasilkan proses belajar yang lebih berkelanjutan. Dengan motivasi belajar yang tinggi dalam belajar maka akan terwujud sikap disiplin sehingga diharapkan dapat mencapai tujuan yang dikehendaki yaitu keberhasilan dalam pendidikan.

Berdasarkan pembahasan tersebut maka dapat disimpulkan bahwa H3 dari penelitian yaitu Peran Pendamping dan Motivasi Belajar secara bersama-sama berpengaruh terhadap Perubahan Perilaku Pengelolaan Keuangan Keluarga Penerima Manfaat (KPM) Program Keluarga Harapan (PKH) Kecamatan Suruh diterima. Hasil dari penelitian ini relevan dengan penelitian yang dilakukan terdahulu yang menyebutkan bahwa peran guru dan motivasi belajar berpengaruh pada perubahan perilaku pengelolaan keuangan sebagai hasil belajar. Semakin baik peran guru dan semakin tinggi motivasi belajar maka semakin baik perubahan perilaku pengelolaan keuangan. Pengambilan variabel Peran Pendamping dan Motivasi Belajar berdasar pada pemikiran bahwa peran pendamping merupakan faktor eksternal dan motivasi belajar merupakan faktor internal yang mempengaruhi perubahan perilaku sebagai hasil belajar. Masih terdapat banyak faktor lain yang mempengaruhi perubahan perilaku pengelolaan keuangan seperti faktor lingkungan, tingkat pendidikan, usia, kedisiplinan, dan tingkat ekonomi.

\section{PENUTUP}

Berdasarkan hasil penelitian dan pembahasan maka dapat disimpulkan bahwa pengaruh peran pendamping terhadap perubahan perilaku pengelolaan keuangan KPM PKH Kecamatan Suruh bernilai positif, motivasi belajar berpengaruh positif terhadap perubahan perilaku pengelolaan keuangan KPM PKH Kecamatan Sururh. Variabel peran pendamping dan motivasi belajar secara parsial maupun simultan mempengaruhi perubahan perilaku pengelolaan keuangan Keluarga Penerima Manfaat (KPM) Program Keluarga Harapan di Kecamatan Suruh, namun tetap ada faktor lain diluar penelitian ini yang turut mempengaruhi perubahan perilaku pengelolaan keuangan Keluarga Penerima Manfaat (KPM) Program Keluarga Harapan di Kecamatan Suruh. yang berarti semakin tinggi pengaruh peran pendamping maka akan semakin tinggi perubahan perilaku pengelolaan keuangan.

Penelitian ini memiliki keterbatasan waktu, ruang lingkup penelitian, dan hanya 
membahas Modul Pengelolaan Keuangan dan Perencanaan Usaha. Diharapkan ada penelitian lanjutan yang berkaitan dengan penelitian ini yang ditinjau dari variabel independen atau dependen lain mengingat pada modul kegiatan Pertemuan Peningkatan Kemampuan Keluarga (P2K2) masih terdapat empat modul lain. Bagi Keluarga Penerima Manfaat (KPM) Program Keluarga Harapan (PKH) sebaiknya lebih meningkatkan motivasi belajar serta lebih mendalami dan mempraktikkan isi modul yang ada pada kegiatan Pertemuan Peningkatan Kemampuan Keluarga (P2K2) khususnya pada Buku Pintar Pengelolaan Keuangan dan Perencanaan Usaha dalam usaha perubahan perilaku pengelolaan keuangan.

\section{DAFTAR PUSTAKA}

Amanah, S. 2007. Makna Penyuluhan dan Transformasi Perilaku Manusia. J. Penyuluhan. 3(1): 63-67

Astriyani. Triyono. dan I. Hitipeuw. 2018. Hubungan Motivasi Belajar dan Tindakan Guru dengan Prestasi Belajar Siswa dengan Latar Belakang Broken Home Kelas V Sekolah Dasar. J. Pendidikan. 3(6): 806-809

Budiwibowo, A.K. dan K. Nurhalim. 2016. Pengaruh Motivasi Belajar Terhadap Prestasi Belajar Warga Belajar Kejar Paket C. Journal of Nonformal Education. 2(2) : 168-174

Cummins, M., J.H. Haskel, dan S. Jenkins. 2009. Financial Attitudes and Spending Habits of University Fresmen. Journal of Economics and Economic Education Research. 10(1): 3-6

Dubois, B. dan K. Miley. 2005. Social Work: An Empowering Profession. Boston: Allyn and Bacon

Ghozali, I. 2011. Aplikasi Analisis Multivariate Dengan Program SPSS. Semarang: Badan Penerbit Universitas Diponegoro

Habibullah. 2011. Peran Pendamping pada Program Keluarga Harapan Kab. Karawang. J. Informasi (Kajian Permasalahan Sosial dan Usaha Kesejahteraan Sosial). 16(2): 101-116

Hamalik, O. 2011. Kurikulum dan Pembelajaran. Jakarta: Bumi Aksara
Hogarth, J.M. dan C.E. Angelov. 2003. Can The Poor Save? Assosiation for Financial Counseling and Planning Education

Kamil, M. 2012. Model Pendidikan dan Pelatihan. Bandung: Alfabeta

Mandell, L. dan L.S. Klein. 2007. Motivation and Financial Literacy. Financial Service Review 16. 105-116

Margono. 2004. Metodologi Penelitian Pendidikan. Jakarta: Rineka Cipta

Purwanti, P. 2019. Peran Pendamping Program Keluarga Harapan dalam Pemberdayaan Masyarakat Miskin di Kecamatan Magelang Selatan. J. Pendidikan Luar Sekolah. 8(4) : 412420

Purwidianti, W. dan R. Mudjiyanti. 2016. Analisis Pengaruh Pengalaman Keuangan dan Tingkat Pendapatan terhadap Perilaku Keuangan Keluarga di Kecamatan Purwokerto Timur. BENEFIT Jurnal Manajemen dan Bisnis. 1(2): 141-148

Putri, A.T.K. dan M.F. Ma'ruf. 2016. Pemberdayaan Masyarakat Miskin Melalui Program Keluarga Harapan Studi Pada Kegiatan Family Development Sessions di Desa Manduro Manggunggajah Kecamatan Ngoro Kabupaten Mojokerto. Publika Jurnal Administrasi Negara. 4(1) : 1-18

Rachmat, H.H. (2018). Penguatan Upaya Kesehatan Masyarakat dan Pemberdayaan Masyarakat Bidang Kesehatan di Indonesia. Yogyakarta: Gajah Mada University Press

Rahayu, L.T.I. 2016. Hubungan Minat Membaca dan Motivasi Belajar dengan Hasil Belajar Materi Menulis Karangan pada Warga Belajar Kejar Paket C di PKBM Al-Firdaus Kabupaten Serang. J. Eksistensi Pendidikan Luar Sekolah. 1(2) : 188-201

Sanjaya, W. 2007. Strategi Pembelajaran: Berorientasi Standar Proses Pendidikan. Jakarta: Kencana

Sartika, S.H. D. Dahlan. dan I. Waspada. 2018. Kompetensi Guru dan Motivasi Belajar Siswa terhadap Hasil Belajar 
melalui Kebiasaan Belajar Siswa. J. Manajerial. 3(4): 39-51

Setyawati, V. dan Subowo. 2018. Pengaruh Motivasi Belajar, Lingkungan Keluarga, dan Peran Guru terhadap Disiplin Belajar Siswa. Economic Education Analysis Journal. 7(1): 29-44

Slameto. 2010. Belajar dan Faktor yang mempengaruhinya. Jakarta: Rineka Cipta

Sugiyono. 2008. Metode Penelitian Kuantitatif Kualitatif dan R\&D. Bandung: Alfabeta

Suhana, C. 2014. Konsep Strategi Pembelajaran. Bandung: Refika Aditama

Suprihatin, S. 2015. Upaya Guru dalam Meningkatkan Motivasi Belajar Siswa. J. Pendidikan Ekonomi. 3(1) : 73-82

Suryana, A., D. Sugiana dan P. Trulline. 2016. Pengaruh Atribut Agen Perubahan (Agent of Change) Pendamping Program Keluarga Harapan (PPKH) terhadap Perubahan Sikap Rumah Tangga Sangat Miskin (RTSM) Peserta Program Keluarga Harapan (PKH) di Kabupaten Bandung. J. Manajemen Komunikasi. 1(1) : 5-41

Trisnaningsih, S. dan F. Widyasari. 2010. Manajemen Pengelolaan dan Perencanaan Keuangan Keluarga pada Ibu Rumah Tangga di Kawasan Siwalan Kerto Surabaya. J. Strategi Akuntansi. 2(1): 1-32 